UDK 579:662.7

\title{
ISOLATION AND STUDY OF THE MAIN PROPERTIES OF ACIDOPHILIC CHEMOLITHOTROPHIC BACTERIA ISOLATED FROM THE WASTE DUMPS OF FUEL-ENERGY COMPLEX IN UKRAINE
}

\author{
I. Blayda*1, T. Vasylieva1, L. Sliusarenko', \\ N. Vasylieva', V. Baranov' ${ }^{2}$ S. Shuliakova \\ ${ }^{1}$ Odesa I. I. Mechnikov National University, 2, Dvoryanska St., Odesa 65082, Ukraine \\ 2Ivan Franko National University of Lviv, 4, Hrushevskyi St., Lviv 79005, Ukraine \\ *e-mail: iblayda@ukr.net
}

Blayda I., Vasylieva T., Sliusarenko L., Vasylieva N., Baranov V., Shuliakova S. Isolation and study of the main properties of acidophilic chemolithotrophic bacteria isolated from the waste dumps of fuel-energy complex in Ukraine. Studia Biologica, 2018: 12(3-4); 3-16 • https://doi.org/10.30970/ sbi. 1203.570

Pure cultures of the acidophilic chemolithotrophic bacteria that are mesophilic and moderately thermophilic, were isolated from the acidophilic aboriginal association of the microorganisms from the waste dumps by fuel-energy complex of Ukraine. Their basic biological and applied properties studied. The main differences of the studied strains in relation to energy substrates were noted. One group of bacteria, according their ability to oxidize a wide range of energy sources, in particular iron (II), was referred to Acidithiobacillus ferrooxidans. Another group of bacteria, according their ability to oxidize preferentially sulfur and its reduced compounds, was referred to Acidithiobacillus thiooxidans. All mesophilic strains regardless of the source of isolation were characterized by approximately the same growth ability and biomass accumulation. However, the intensity of oxidation of ferrous iron was different and did not depend on the amount of the biomass. A comparative analysis of obtained results has allowed considering that strains of $A$. ferrooxidans Lv red 9 and $A$. ferrooxidans Lv black 37 have maximum oxidative activity. Their example shows the ability of adaptation to new substrates, using them as an additional source of microelements and energy. A high level of the isolated strains leaching activity has been established. Both adapted and unadapted strains were able to leach rare metals - gallium and germanium from waste products (65.0 and $78.0 \%$, respectively). The efficiency of extraction of other metals such as copper, lead, zinc, nickel, and aluminum was slightly lower and depended on the origin of the substrate and on the properties of the strain. However, even this level of biological leaching is sufficient to reduce the toxicity of

(C) 2018 I. Blayda et al.; Published by the Ivan Franko National University of Lviv on behalf of Біологічні Студії / Studia Biologica. This is an Open Access article distributed under the terms of the Creative Commons Attribution License (http://www.budapestopenaccessinitiative.org/ and Creative Commons Attribution 4.0 License), which permits unrestricted reuse, distribution, and reproduction in any medium, provided the original work is properly cited.

ISSN 1996-4536 (print) • ISSN 2311-0783 (on-line) • Біологічні Студії / Studia Biologica • 2018 • Том 12/№3-4 • С. 3-16 
waste dumps. The obtained results allow concluding about the wide distribution of representatives of the Acidithiobacillus genus in the dumps of the fuel-energy complex, their biological diversity, and a possibility of their use in biotechnologies of metal leaching.

Keywords: acidophilic chemolithotrophic bacteria, dumps of fuel-energy complex, adaptation, leaching activity, germanium, gallium

\section{INTRODUCTION}

Ecological niches with high content of sulfur and iron in particular sulfide ores, quarry and mine waters, geothermal zones, tailings, slags and slurries after the extraction and processing of natural ores are the main habitats of acidophilic chemolithotrophic bacteria (ACB). A large number of Acidithiobacillus ferrooxidans and Acidithiobacillus thiooxidans strains, characterized by a wide variety of properties have been isolated from such ecological niches. Acidithiobacillus ferrooxidans that inhabit in different natural zones and are adapted to specific substrates distinct from each other in growth rate, rate of ferrous iron oxidation, and the efficiency of leaching. The ability of ACB to oxidize sulfide minerals is now widely used in bio-hydrometallurgical technologies with the purpose of receiving non-ferrous and noble metals from sulfide ores [5-7, 11]. At present, the capability of Acidithiobacillus ferrooxidans and Acidithiobacillus thiooxidans to extract copper, gold, uranium, cobalt, etc. from poor natural raw materials, concentrates and industrial waste with a high content of target metals is studied [5-7, 11]. Theoretically, this group of bacteria should be present in fossil coals and in the waste dumps from its extraction and processing. Currently, information about the presence, species diversity and properties of ACB in waste dumps of products by the fuel-energy complex (FEC) is not enough. The authors [3,4] obtained data on the presence of chemolithotrophic representatives of microbiocenoses, both mesophilic and moderately thermophilic, in the waste dumps fuel-energy products, as well as a confirmation of their activity. This group of bacteria have a big impact on the changes occurring in the technogenic raw materials in the process of stock and storage. These bacteria are producers of sulfuric acid and in the process of vital activity they extract metals from substrates and introduce metals into the environment. Active ACB, in particular specific strains of $A$. ferrooxidans, can be effectively used for the extraction of metals from waste dumps products by the fuel-energy complex. Therefore, it is very important to carry out applied microbiological studies of technogenic raw materials as a result of which new highly active strains of ACB have been isolated. That could be the basis for new efficient biotechnologies aimed at isolating leaching metals.

The purpose of this work was to isolate the ACB from the native microbial communities of waste dumps by the FEC of Ukraine study their basic biological and practically useful properties important for the biotechnology of metal leaching.

\section{MATERIALS AND METHODS}

Acidophilic chemolithotrophic bacteria isolated from waste dumps by the FEC of Ukraine, or from waste dumps of Central Enrichment Plant (CEP) of the Lviv-Volyn Coal Basin (LVCB) were studied. ACB were isolated from waste dumps of CEP of different storage life (24-28 months - black color and more than 60 months - red color), ash and slag waste and fly ash after burning coal at Dobrotvir and Ladyzhyn thermal power plants (TPP), respectively.

ISSN 1996-4536 (print) • ISSN 2311-0783 (on-line) • Біологічні Студії / Studia Biologica • 2018 • Том 12/№3-4 • С. 3-16 
Isolation, cultivation and studies of mesophilic strains were carried out with using Silverman-Lundgrem 9K liquid and dense medium (composition, g/dm ${ }^{3}: \mathrm{K}_{2} \mathrm{HPO}_{4}-0.50$; $\left.\left(\mathrm{NH}_{4}\right)_{2} \mathrm{SO}_{4}-3.0 ; \mathrm{MgSO}_{4} \cdot 7 \mathrm{H}_{2} \mathrm{O}-0.50 ; \mathrm{KCl}-0.10 ; \mathrm{Ca}\left(\mathrm{NO}_{3}\right)_{2}-0.01\right)$, moderately thermophilic with using medium $9 \mathrm{~K}^{*}$ (composition, g/dm $\mathrm{dm}_{2} \mathrm{KH}_{4} \mathrm{PO}_{4}-0.05 ;\left(\mathrm{NH}_{4}\right)_{2} \mathrm{SO}_{4}-0.45$; $\mathrm{MgSO}_{4} \times 7 \mathrm{H}_{2} \mathrm{O}-0.50 ; \mathrm{KCl}-0.10 ; \mathrm{Ca}\left(\mathrm{NO}_{3}\right)_{2}-0.014$; yeast extract -0.02$)$. Ferrous iron was added to the mineral background of nutrient media as an energy source $\left(\mathrm{FeSO}_{4} \times\right.$ $7 \mathrm{H}_{2} \mathrm{O}$ ) in a concentration of $12.0 \mathrm{~g} / \mathrm{dm}^{3}$ (to enhance biomass growth) and $44.5 \mathrm{~g} / \mathrm{dm}^{3}$ (for leaching metals ) or thiosulfate and/or sulfur in concentration $5.0 \mathrm{~g} / \mathrm{dm}^{3}[5-7]$. Obtaining ACB was carried out by the method of enrichment culture media. Cultivation of mesophilic ACB was carried out at $30.0 \pm 0.5^{\circ} \mathrm{C}$, moderately thermophilic - at $45.0 \pm 0.5^{\circ} \mathrm{C}$ within 3-5 days. Changes in the $\mathrm{pH}$ of the culture fluid, the appearance of light turbidity and film on the surface of the median indicated to the development of microorganisms. Primary isolates were purified by way of subcultivation on liquid and dense medium to a microscopically and colonially homogeneous state. After microscopic examination, it was concluded that a pure culture was obtained. For pure cultures, Gram staining was performed, the range and optimal values of temperature and $\mathrm{pH}$, the ability to autotrophic and mixotrophic growth, oxidation of various energy sources, and ability to use of organic substances were determined. The morphology of the cells and the colonies formed by them have been studied using Primo Star PC light (Germany) and electronic PEM100-01 (Ukraine) microscopes.

To identify strains by polymerase chain reaction (PCR) primers F1_Thio (Sense) and R1_Thio (Antisense) with ATGCGTAGGAATCTGTCTTT and GGACTTAACCCAACATCTCA sequence for $A$. ferrooxidans and TCTTCGGACCTCGCGCTGG and GTCAACAGCAGGCGATATTAGCAC for $A$. thiooxidans were used. To determine the diversity of strains RAPD-PCR and used primer M13: 5'GAGGGTGGCGGTTCT3' was carried out.

Growth rate of the biomass was determined using a DR 3900 spectrophotometer (Germany) at a wavelength of $540 \mathrm{~nm}$ and expressed in units of optical density (D). At the beginning of the experiment, $50.0 \mathrm{ml}$ of the appropriate nutrient medium and suspension of the test strain with an initial bacterial concentration of $7.5 \pm 1,5 \times 10^{6} \mathrm{cells} / \mathrm{ml}$ (0.1 D) at a concentration of $2.0 \% / \mathrm{Vol}$ were added to the flasks. Cultivation was carried out for 7 days. The oxidation of energy sources and the efficiency of the oxidation process is the most important function of ACB. Therefore, when determining the growth rate and biomass accumulation of those strains were studied, the change in the concentration of iron(II) in the nutrient medium were also controlled.

Adaptation of ACB strains was carried out for 4 days (cultivation in $9 \mathrm{~K}$ medium), and in this case red and black dumps using as an additional source of trace elements and energy. The ratio of solid phase: solution (SP:S) was 1:2, 1:3 and 1:10. The growth rate of strains in $9 \mathrm{~K}$ medium with $12.0 \mathrm{~g} / \mathrm{dm}^{3}$ of $\mathrm{FeSO}_{4} \times 7 \mathrm{H}_{2} \mathrm{O}$ was considered as a control.

The ability of cultures to leach metals from waste dumps by the fuel-energy complex (FEC) was evaluated. Observations have been conducted in the next conditions: ratio of the solid phase: solution was $1: 10, \mathrm{pH} \leq 2.0,30.0 \pm 0.5^{\circ} \mathrm{C}$ with abidance of sterile conditions and with occasional stirring during 7 days. The metal content in solution was determined by the atomic absorption spectroscopy AAS devices-1 (Germany) and C-115PK Selmi (Ukraine). Sterile dumps and sterile environment without bacteria were considered as a control. The reliability of the obtained results was evaluated by the Student's criterion with a probability of $p<0.05$. 
Identical studies were carried out with Acidithiobacillus ferrooxidans ATCC 23270 strain isolated from brown coal mines in the United States. It is registered in the American Type Culture Collection (Rockville, Mertland, USA). All strains used in studies are stored in the museum of the Department of Microbiology, Virology and Biotechnology of the Odesa I.I. Mechnikov National University.

\section{RESULTS AND DISCUSSION}

As a result of this work, we have been isolated 59 strains of acidophilic chemolithotrophic bacteria from black and red waste dumps of Central Enrichment Plant (CEP), ash and slag waste and fly ash after burning coal. Among them there were 29 mesophilic strains that oxidize iron, sulfur and thiosulfate; 17 mesophilic strains oxidize only sulfur and thiosulfate and 13 moderately thermophilic strains have capacity to use iron, sulfur and thiosulfate. After the study of biological and molecular genetic properties 9 cultures of the ACB were selected for further work. These strains rapidly grew and were representative in relation to substrate as a source of isolation. We have paid particular attention to mesophilic ACB because the applied nature of the research is the development of cost-effective biotechnology. After studying the biological and molecular genetic properties of these strains, they assigned unique numbers (Table 1).

Table 1. Strains of acidophillic chemolithotrophic bacteria isolated from dumps of fuelenergy complex

Таблиця 1. Штами ацидофільних хемолітотрофних бактерій, виділені 3 відвальних продуктів паливно-енергетичного комплексу

\begin{tabular}{|c|c|c|}
\hline $\mathrm{N}$ & Strain & Source of isolation \\
\hline 1 & Acidithiobacillus ferrooxidans Lv red 9 & $\begin{array}{l}\text { Red waste dumps from CEP } \\
\text { "Chervonogradska", Lviv region, Ukraine }\end{array}$ \\
\hline 2 & Acidithiobacillus ferrooxidans Lv black 37 & $\begin{array}{l}\text { Red waste dumps from CEP } \\
\text { "Chervonogradska", Lviv region, Ukraine }\end{array}$ \\
\hline 3 & Acidithiobacillus ferrooxidans DTV 1 & $\begin{array}{l}\text { Ash and slag waste of Dobrotvir TPP, } \\
\text { "DFEC Zakhidenergo", Lviv region, Ukraine }\end{array}$ \\
\hline 4 & Acidithiobacillus ferrooxidans Lad 5 & $\begin{array}{l}\text { Fly ash of Ladyzhynska TPP } \\
\text { "DFEC Zakhidenergo", Vinnytsia region, Ukraine }\end{array}$ \\
\hline 5 & Acidithiobacillus ferrooxidans Lad 27 & $\begin{array}{l}\text { Fly ash of Ladyzhynska TPP, } \\
\text { "DFEC Zakhidenergo", Vinnytsia region, Ukraine }\end{array}$ \\
\hline 6 & $\begin{array}{l}\text { Acidithiobacillus thiooxidans } \\
\text { Lv red } 11\end{array}$ & $\begin{array}{l}\text { Red waste dumps from CEP } \\
\text { "Chervonogradska", Lviv region, Ukraine }\end{array}$ \\
\hline 7 & Acidithiobacillus thiooxidans DTV 5 & $\begin{array}{l}\text { Ash and slag waste of Dobrotvir TPP, } \\
\text { "DFEC Zakhidenergo", Lviv region, Ukraine }\end{array}$ \\
\hline 8 & $\begin{array}{l}\text { Acidithiobacillus thiooxidans } \\
\text { Lv black } 6\end{array}$ & $\begin{array}{l}\text { Black dump from CEP "Chervonogradska", } \\
\text { Lviv region, Ukraine }\end{array}$ \\
\hline 9 & Sulfobacillus sp. Lad 29 & $\begin{array}{l}\text { Fly ash of Ladyzhynska TPP } \\
\text { "DFEC Zakhidenergo", Vinnytsia region, Ukraine }\end{array}$ \\
\hline
\end{tabular}

Depending on their ability to use energy sources the isolated mesophilic strains, were conventionally divided into two groups: strains that oxidize ferrous iron, sulfur and its compounds were assigned to $A$. ferrooxidans; strains that oxidize only sulfur and its compounds were assigned to $A$. thiooxidans. The basic properties of $A$. ferrooxidans $L V$ red 9, A. ferrooxidans Lv black 37, $A$. ferrooxidans DTV 1 , $A$. thiooxidans Lv black 6 , as

ISSN 1996-4536 (print) • ISSN 2311-0783 (on-line) • Біологічні Студії / Studia Biologica • 2018 • Том 12/№3-4 • С. 3-16 
well as the main features of the typical strain Acidithiobacillus ferrooxidans ATCC 23270 are shown in Table 2. Some of previously studied properties of Sulfobacillus sp. Lad 29 strain has already been described in [3].

The fuel-energy complex mesophilic bacteria isolated from waste dumps regardless of the energy source, differ slightly from each other in morphology. These were mainly Gram-negative small, short, straight, sometimes slightly bent, arranged in pairs or in short chains of rod-shaped non-sporing cells, similar to those shown on micrographs of $A$. ferrooxidans Lv black 37 (Fig. 1).

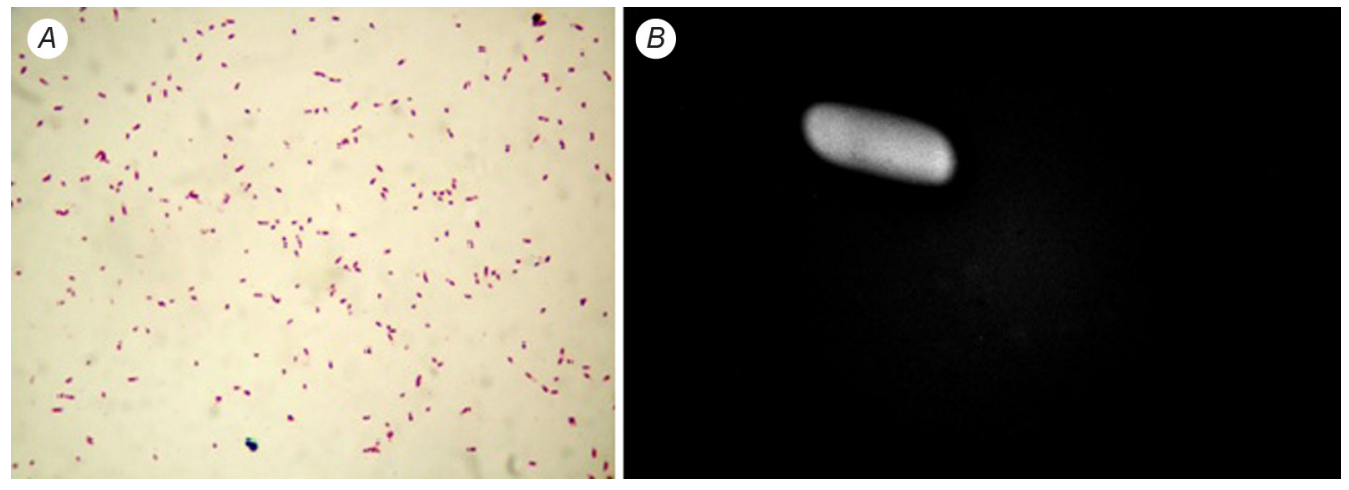

Fig. 1. Mesophilic strain Acidithiobacillus ferrooxidans Lv black 37: $A$ - microbial drug, magnification $\times 1000$; $B$ - electronic photo, magnification $\times 12000$

Рис. 1. Мезофільний штам Acidithiobacillus ferrooxidans Lv black 37: $A$ - забарвлений мікроскопічний препарат, збільшення х1000; $B$ - електронна фотографія, збільшення ×12 000

At microscopic examination cells of all the studied strains of $A$. ferrooxidans did not practically differ in shape and size but in the process of growth on agar medium they formed colonies of various morphological types depending on the energy source. For example, at growth on dense media $9 \mathrm{~K}$ with ferrous iron the development of homogeneous point convex yellowish-rusty or lemon-colored granular colonies was observed (Fig. $2 \mathrm{~A}$ ). When thiosulfate was added to the mineral background of the $9 \mathrm{~K}$ medium, the bacteria formed dotted colorless colonies with a metallic sheen on the surface of the medium (Fig. $2 B$ ). At growth on dense media with thiosulfate colony of $A$. thiooxidans Lv black 6 were the same in shape and size (Fig. 2 C).
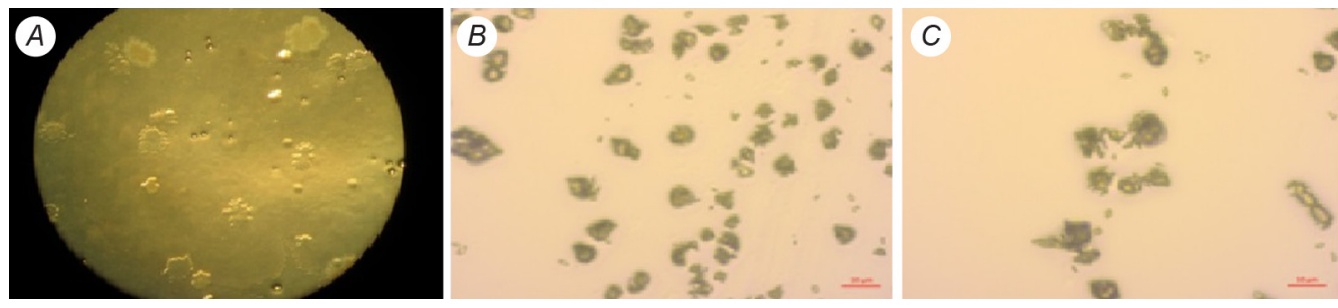

Fig. 2. Microcolonies of Acidithiobacillus ferrooxidans Lv black 37 on medium with ferrous iron ( $A$; magnification $\times 28)$ and thiosulfate $(B$; magnification $\times 1000)$; $A$. thiooxidans Lv black 6 on a medium with thiosulfate $(C$; magnification $\times 1000)$

Рис. 2. Мікроколонії Acidithiobacillus ferrooxidans Lv black 37 на середовищі з двовалентним ферумом $(A$; збільшення ×28) і тіосульфатом (B; збільшення ×1000); $A$. thiooxidans Lv black 6 на середовищі 3 тіосульфатом $(C ;$ збільшення $\times 1000)$

ISSN 1996-4536 (print) • ISSN 2311-0783 (on-line) • Біологічні Студії / Studia Biologica • 2018 • Том 12/№3-4 • С. 3-16 
The cells of moderately thermophilic bacteria were presented by short, thick, rounded ends, coccoid, gram-positive spore-forming cells (Fig. 3). On the surface of the dense medium, they formed dotted colonies of lemon or yellow color.

Isolated mesophilic strains on the basis of their biological properties and in accordance with Bergey's Manual of Determinative Bacteriology as well as other works [2, 8], have been assigned to Acidithiobacillus ferrooxidans and Acidithiobacillus thiooxidans (depending on the energy sources that they use). Moderately thermophilic strain can be assigned to Sufobacillus sp. The final conclusion was done on the PCR results (data are currently in publication).

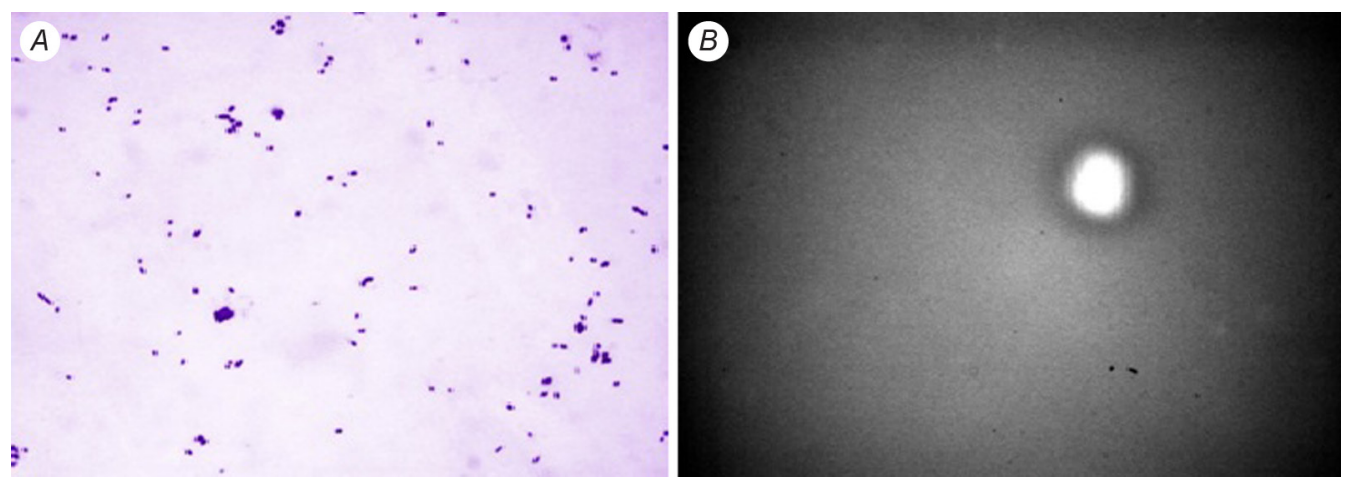

Fig. 3. Moderately thermophilic strain Sulfobacillus sp. Lad 29: $A$ - microbial drug, magnification $\times 1000$; $B-$ electronic photo, magnification $\times 12000$

Рис. 3. Помірно термофрільний штам Sulfobacillus sp. Lad 29: $A$ - забарвлений мікроскопічний препарат, збільшення $\times 1000 ; B$ - електронна фротографрія, збільшення $\times 12000$

The ability to grow and the ability of the heterogeneous cell population to increase the rate of growth are important technological characteristics of microorganisms. For strains of Acidithiobacillus ferrooxidans used in biotechnology which grow relatively slowly, this is a very important characteristic. This is due to the fact that $A$. ferrooxidans use non-energy-intensive inorganic substrates - sulfur, sulfur compounds or iron (II). Therefore, primarily for the processes of bioleaching of metals are selected strains that have a maximum growth rate and are capable of accumulating a significant amount of biomass. Moreover, these strains can be used both independently and as part of bacterial preparations. For the selection of strains with a maximum growth rate and capability to accumulation of a significant amount of biomass under mixotrophic conditions (Table 2) yeast extract or glucose were added to the nutrient medium $9 \mathrm{~K}$ as an additional growth factor. The sterile medium without bacteria was considered as a control. It was established that yeast extract and glucose have different effect on the growth of the studied strains: the yeast extract either did not have impact or stimulated the growth of the studied strains, glucose either did not have impact or suppressed their growth (Fig. 4).

According to the obtained results, isolated and type strains $A$. ferrooxidans ATCC 23270 can be arranged in a row according decrease the biomass buildup in mixotrophic conditions: A. ferrooxidans Lv red $9>$ A. ferrooxidans Lad $5>$ A. ferrooxidans Lv black $37 \geq$ A.ferrooxidans Lad $27>$ A.ferrooxidans DTV $1>$ A. ferrooxidans ATCC 23270 and at autotrophic conditions:

ISSN 1996-4536 (print) • ISSN 2311-0783 (on-line) • Біологічні Студії / Studia Biologica • 2018 • Том 12/№3-4 • С. 3-16 


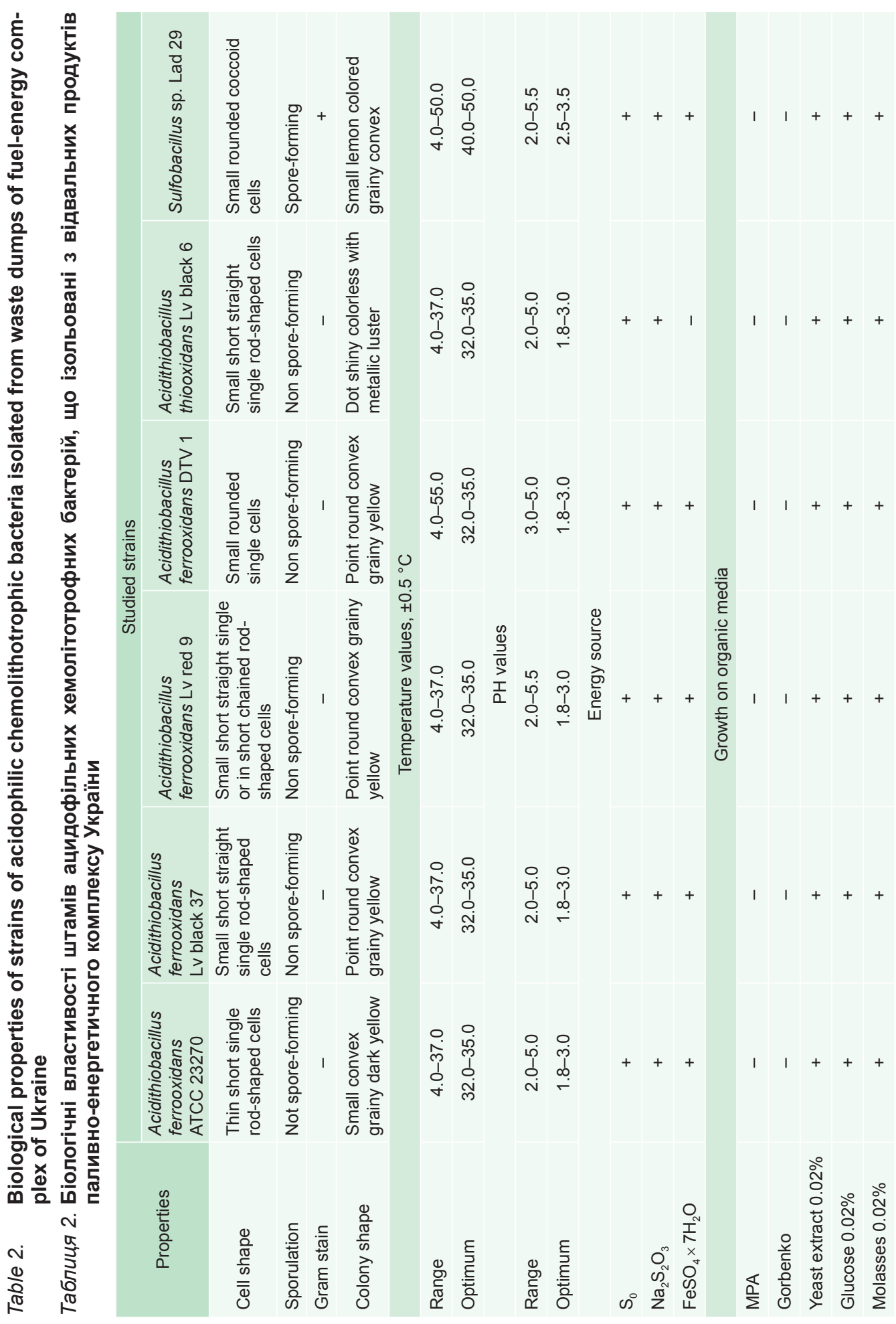

ISSN 1996-4536 (print) • ISSN 2311-0783 (on-line) • Біологічні Студії / Studia Biologica • 2018 • Том 12/№3-4 • С. 3-16 
A. ferrooxidans Lv black $37 \geq$ A.ferrooxidans Lad $27 \geq A$. ferrooxidans Lad $5>$ A. ferrooxidans LV red $9>$ A. ferrooxidans DTV $1>$ A.ferrooxidans ATCC 23270.

According to the results of studies the strain $A$. ferrooxidans DTV 1 and the typical strain A. ferrooxidans ATCC 23270 were least productive among all studied strains regardless of the cultivation conditions.

Oxidation of ferrous iron as an energy source is the main indicator of the A. ferrooxidans strains activity. In the presence of ACB and maintaining acidic conditions $(\mathrm{pH} \leq 2)$ are necessary for oxidation process by the reaction:

$$
4 \mathrm{Fe}^{2+}+\mathrm{O}_{2}+4 \mathrm{H}^{+} \text {bacterium } 4 \mathrm{Fe}^{3+}+2 \mathrm{H}_{2} \mathrm{O}
$$

As a result of this reaction of forming a strong oxidant $-\mathrm{Fe}(\mathrm{III})$ high redox potential in the nutrient medium and increases the efficiency of the metal extraction process are created $[6,7]$.

A

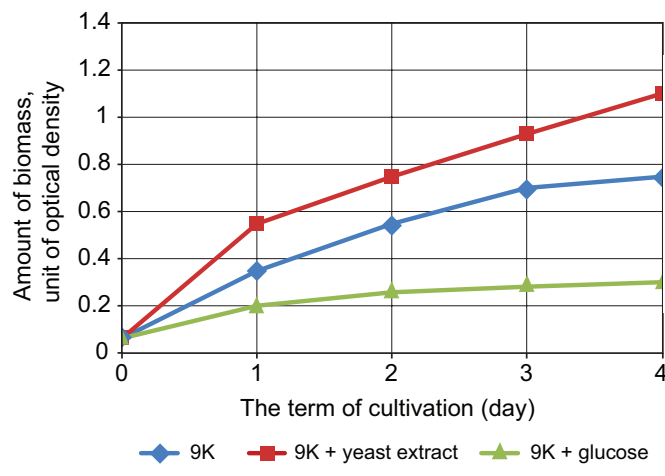

C

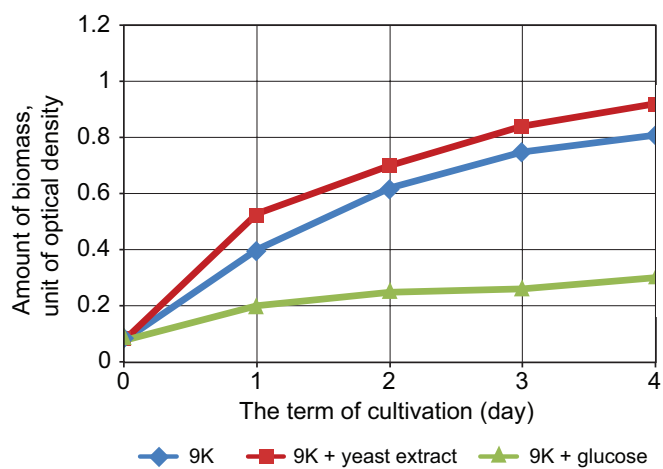

$B$

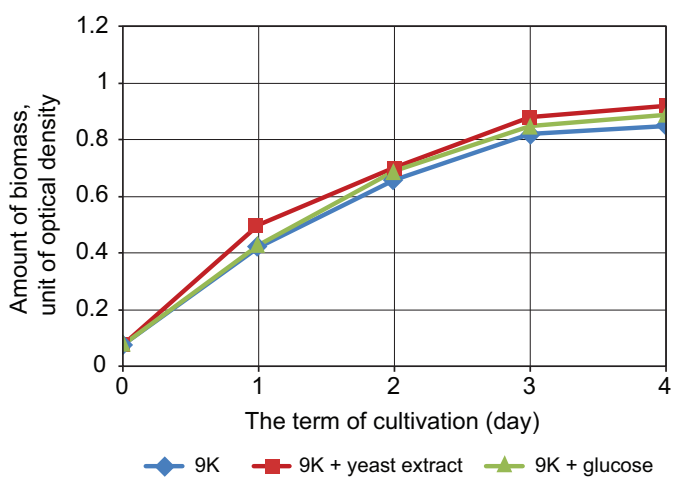

$D$

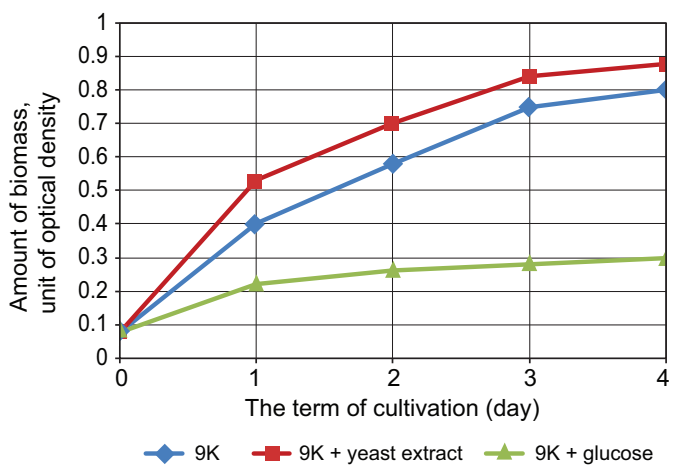

Fig. 4. Growth of Acidithiobacillus ferrooxidans Lv red $9(A)$, Acidithiobacillus ferrooxidans Lv black $37(B)$, Acidithiobacillus ferrooxidans Lad $27(C)$, Acidithiobacillus ferrooxidans Lad $5(D)$ in autotrophic and mixotrophic conditions

Pиc. 4. Ріст Acidithiobacillus ferrooxidans Lv red $9(A)$, Acidithiobacillus ferrooxidans Lv black 37 (B), Acidithiobacillus ferrooxidans Lad $27(C)$, Acidithiobacillus ferrooxidans Lad $5(D)$ в автотрофрних і міксотрофних умовах

The results of our research hawe shown that the yeast extract stimulate growth of some of the studied strains, but in its presence the iron (II) oxidation did not exceed $45.0 \%$. 
The results of measuring the amount of biomass and the concentration of iron (II) after four days of cultivation of the studied strains of $A$. ferrooxidans under autotrophic conditions are shown in Fig. 5. At continued cultivation (until the stationary phase of development) no changes in the growth dynamics of the strains and iron oxidation were noted. In control, by the close of the measurements, the concentration of iron (II) corresponded to the initial $-12 \mathrm{~g} / \mathrm{dm}^{3}$ by $\mathrm{FeSO}_{4} \times 7 \mathrm{H}_{2} \mathrm{O}\left(2.4 \mathrm{~g} / \mathrm{dm}^{3}\right.$ by $\left.\mathrm{Fe}(\mathrm{II})\right)$.

A comparative analysis of the results showed that the oxidation of iron (II) by mesophilic strains did not depend on the amount of biomass. As shown in Fig. 5, strains of $A$. ferrooxidans LV red 9 and $A$. ferrooxidans Lv black 37 that have been isolated from coal-mining waste dumps are capable to oxidize iron (II) with maximum efficiency a decrease in the concentration of iron (II) was recorded on the level $73-75 \%$.

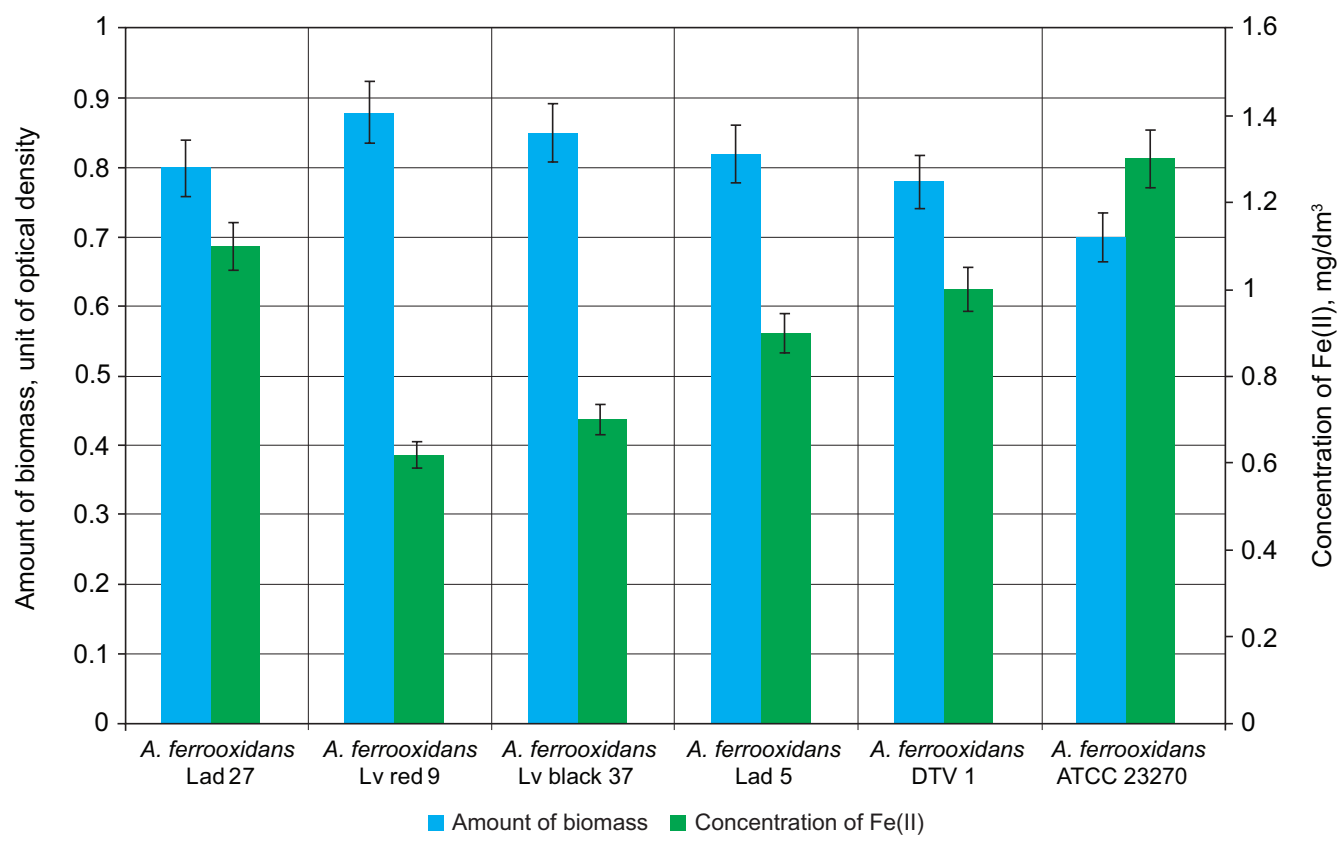

Fig. 5. The amount of biomass and the concentration of non-oxidized iron (II) Acidithiobacillus ferrooxidans strain isolated from the waste dumps of fuel-energy complex

Рис. 5. Кількість біомаси та концентрація неокисленого заліза (II) штамами Acidithiobacillus ferrooxidans, виділеними з відвальних продуктів паливно-енергетичного комплексу

The ability of ACB to adaptation to other substrates is an important practically useful property and it makes possible using one or several strains in association in order to obtain an effective standardized bacterial preparation capable of leaching metals from any waste dumps by the fuel-energy complex of Ukraine, regardless of storage life.

The ability of oxidize irons, sulfur, reduced sulfur compounds, as well as various sulfide minerals are evolutionarily formed properties of all Acidithiobacillus ferrooxidans strains, however, if the oxidation substrate changes, the strains needs an adaptation period. For example, $A$. ferrooxidans Lv black 37, after long cultivation in the presence of $\mathrm{Fe}$ (II), requires a period of adaptation to the "black" dumps from which it was isolated.

ISSN 1996-4536 (print) • ISSN 2311-0783 (on-line) • Біологічні Студії / Studia Biologica • 2018 • Том 12/№3-4 • С. 3-16 
Data shown in Fig. 6 A suggest that when the energy source is changed from ferrous iron to black "native" waste dumps, there was a slight decrease in the amount of bacteria in the initial period of cultivation. The duration of the logarithmic phase of $A$. ferrooxidans Lv black 37 strain in the control was 72 hours, after which the stationary growth phase started. The duration of the logarithmic growth phase of $A$. ferrooxidans Lv black 37 in the control was 72 hours, after which the stationary growth phase began. Cultivation of $A$. ferrooxidans Lv black 37 with ratio of the solid phase: solution as $1: 2$ and 1:3 shortened time to reach of the stationary phase to 48 hours. In this case, the amount of bacteria in the medium was less than in the control. During further cultivation, the amount of cells of the studied strain does not increase, but they remain viable. In this case, low biomass amounts can be explained by the interaction of cells with solid particles in the pulp under conditions of reduced oxygen content. If we reduce the amount of solid substrate to a ratio of 1:10 the amount of bacteria in solution will be approach the indicators in the control throughout cultivation. A decrease in the amount of bacteria at the beginning of the adaptation period can be explained by the phenomenon of immobilization by attaching bacteria to the surface of the substrate [12].

A

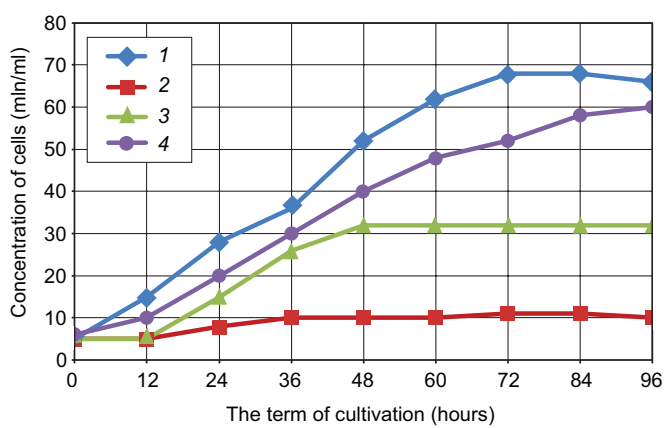

$B$

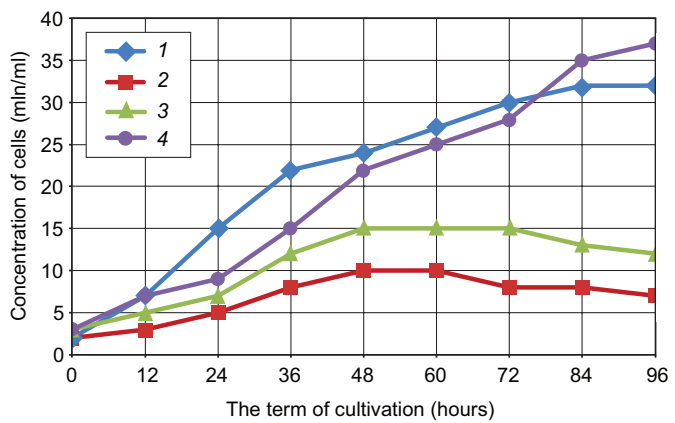

C

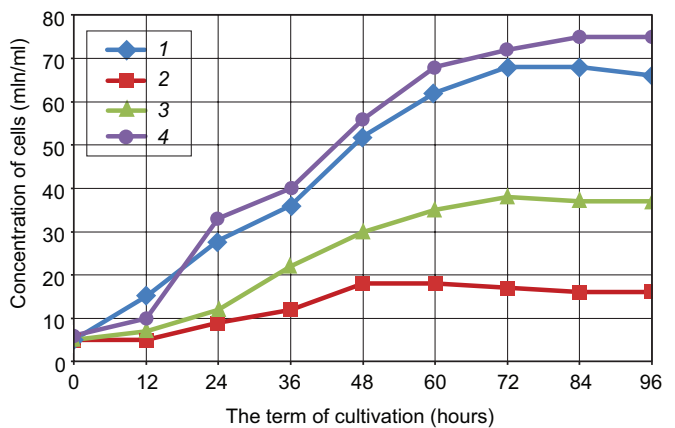

Fig. 6. The amount of Acidithiobacillus ferrooxidans Lv black 37 cells with a growth at presence: 1 $12.0 \mathrm{~g} / \mathrm{dm}^{3} \mathrm{FeSO}_{4} \times 7 \mathrm{H}_{2} \mathrm{O}$ (control); $2-\mathrm{SP}: \mathrm{S}=1: 2 ; 3-\mathrm{SP}: \mathrm{S}=1: 3 ; 4-\mathrm{SP}: \mathrm{S}=1: 10$ black $(A)$ and red (B) dumps; the amount of Acidithiobacillus ferrooxidans Lv red 9 cells with a growth at the presence: $1-12.0 \mathrm{~g} / \mathrm{dm}^{3} \mathrm{FeSO}_{4} \times 7 \mathrm{H}_{2} \mathrm{O} ; 2-\mathrm{SP}: \mathrm{S}=1: 2 ; 3-\mathrm{SP}: \mathrm{S}=1: 3 ; 4-\mathrm{SP}: \mathrm{S}=1: 10$ black dumps $(C)$

Рис. 6. Концентрація клітин Acidithiobacillus ferrooxidans Lv black 37 у разі росту за наявності: 1 12,0 г/дм ${ }^{3} \mathrm{FeSO}_{4} \times 7 \mathrm{H}_{2} \mathrm{O}$ (контроль); $2-\mathrm{T:P}=1: 2 ; 3-\mathrm{T}: \mathrm{P}=1: 3 ; 4-\mathrm{T}: \mathrm{P}=1: 10$ чорних $(A)$ ічервоних $(B)$ відвалів; концентрація Acidithiobacillus ferrooxidans Lv red 9 у разі росту за наявності: 1 12,0 г/дм ${ }^{3} \mathrm{FeSO}_{4} \times 7 \mathrm{H}_{2} \mathrm{O} ; 2-\mathrm{T}: \mathrm{P}=1: 2 ; 3-\mathrm{T:P}=1: 3 ; 4-\mathrm{T:P}=1: 10$ чорних відвалів $(C)$ 
Similar regularities were found when we adapted strain $A$. ferrooxidans Lv black 37 to "non-native" red substrate (Fig. 6 C). At the same time, less dense pulp (SP:S = 1:10) stimulated growth of biomass compared with the control; but the exit to the stationary phase also occured after 72 hours.

In the process of $A$. ferrooxidans Lv red 9 adaptation to black dumps, the same regularities were observed as at the adaptation of $A$. ferrooxidans Lv black 37 to red (Fig. $6 \mathrm{C}$ ). The difference was found only in the amount of biomass: $A$. ferrooxidans LV red 9 was characterized by lower productivity in all variants of experiments.

So, strains isolated from different waste dumps are able to adapt to new "non-native" substrates, use them as a source of microelements and energy, and leach metals from this mineral raw material, regardless of its nature. For adaptation of any A. ferrooxidans strain to new substrates, 72 hours of contact of the bacterial suspension is need with the corresponding substrate by proportion $S P: S=1: 10$.

Leaching activity is the most important technological characteristic of any strain of ACB because it is the indicator that determines the efficiency of extraction of metals from mineral raw materials. It was established that the concentrations of the main controlled metals in the waste dumps by fuel-energy complexes which were studied, significantly exceeded their minimum industrial content and were in the range, g/t: 42.0120.0 of lead; $132.9-170.0$ of nickel; $60.0-92.5$ of copper; $110.0-315.0$ of zinc; $26.0-$ 40.0 of germanium, $15.1-30.0$ of gallium, $(8.92 \pm 0.05) \times 10^{3}-(105.0 \pm 0.1) \times 10^{3}$ of aluminum. The most significant indicators of metal leaching from the studied dumps of fuelenergy complex of Ukraine which were recorded by using isolated "native", adapted "non-native" strains, type strain A.ferrooxidans ATCC 23270 and the corresponding aboriginal association of mesophilic ACB are shown on Fig. 7. The use of the latter option was dictated by the available evidence that mixed cultures and association of microorganisms are more effective and stable under oxidation, in particular, sulfide minerals than pure cultures, due to existing syntrophysic connections between the microorganisms $[1,9,10]$.

The obtained results indicate high leaching activity of the isolated strains to all the extracted metals, especially rare, for example gallium and germanium. General regularity is the fact that the aboriginal associations of mesophilic ACB and "native" strains are most active, but the "non-native" strains are also quite effective. So, the result of studies was the isolation of acidophilic chemolithotrophic bacteria from waste dumps of the fuelenergy complex. The culturally-morphological characteristics of the isolated strains did not differ significantly. Some differences were revealed in relation to the energy source. According to this feature, all mesophilic strains were divided into two groups. The first group including strains that have a capability to oxidize a wide range of energy substrate, in particular $\mathrm{Fe}(\mathrm{II})$. This group includes $A$. ferrooxidans Lv red 9, A. ferrooxidans Lv black 37, A. ferrooxidans Lad 5, A. ferrooxidans Lad 27, A. ferrooxidans DTV 1, Sulfobacillus sp. Lad 29. The second group includes strains that passess a capability to oxidize only sulfur and reduced sulfur compounds $-A$. thiooxidans Lv black 6 , $A$. thiooxidans LV red 11. The features of growth and oxidation of ferrous iron by the studied strains at the autotrophic and mixotrophic conditions were revealed under the conditions of our experiments. It was shown that studied strains, notwithstanding of the isolation source, not significantly different in their ability to grow, however, the oxidation efficiency of iron (II) was different and did not depend on the amount of the biomass. The strains of $A$. ferrooxidans Lv black 37 and $A$. ferrooxidans Lv red 9 were characterized by

ISSN 1996-4536 (print) • ISSN 2311-0783 (on-line) • Біологічні Студії / Studia Biologica • 2018 • Том 12/№3-4 • С. 3-16 


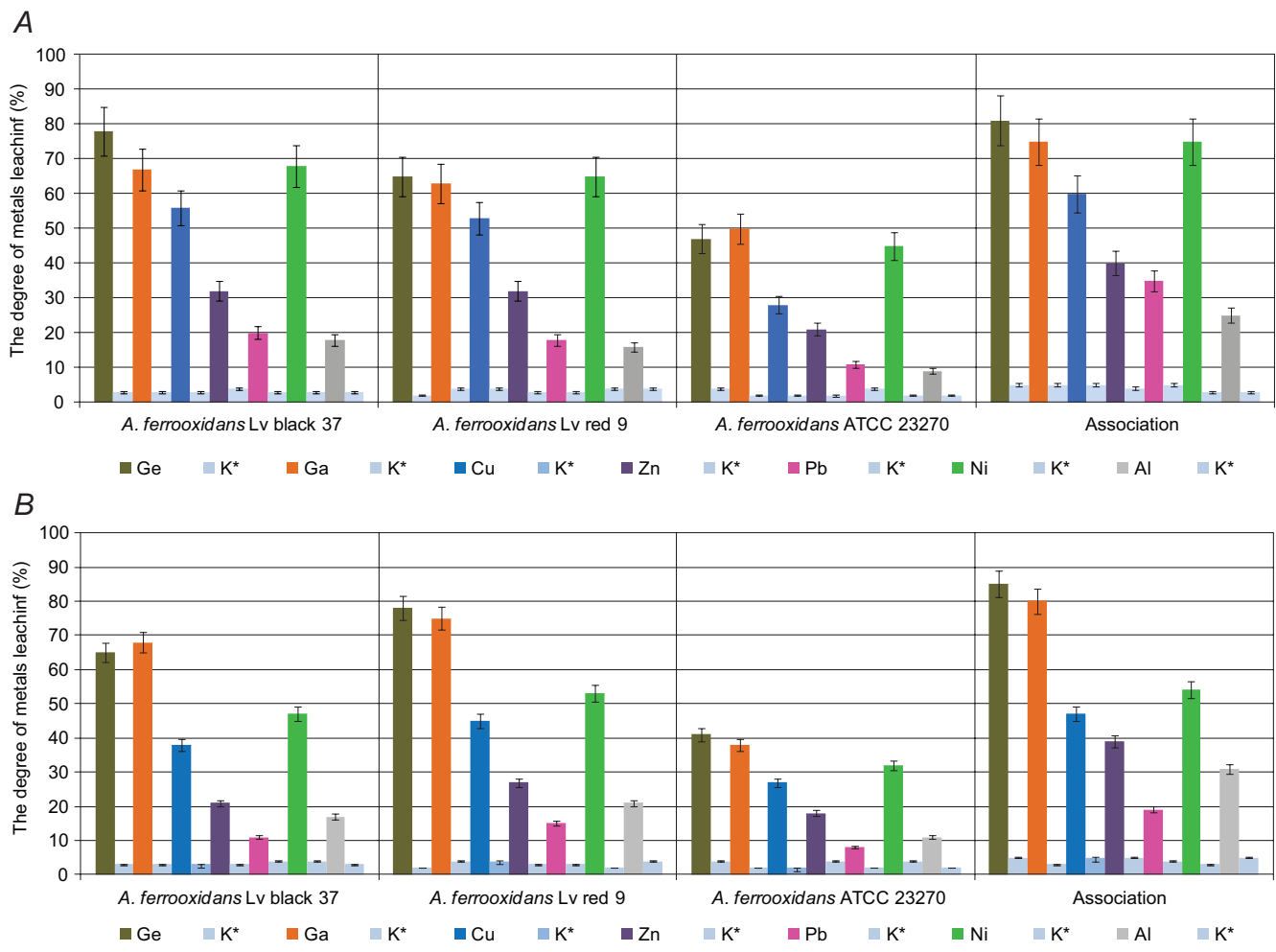

Fig. 7. The leaching of metals from black $(A)$ and red $(B)$ dumps by strains Acidithiobacillus ferrooxidans LV black 37, Acidithiobacillus ferrooxidans Lv red 9, Acidithiobacillus ferrooxidans ATCC 23270 and by aboriginal association of microorganisms $\left(\mathrm{K}^{*}-\right.$ control)

Рис. 7. Вилуговування металів із чорних $(A)$ і червоних $(B)$ відвалів штамами Acidithiobacillus ferrooxidans Lv black 37, Acidithiobacillus ferrooxidans Lv red 9, Acidithiobacillus ferrooxidans ATCC 23270 і аборигенною асоціацією (К * - контроль)

maximum oxidative activity. Oxidation by them of ferrous iron was recorded at the level of 75.0 and $73.0 \%$, respectively. The ability of the studied strains to quickly adapt to new technogenic substrates as to new sources of trace elements and energy was demonstrated. High leaching activity of both adapted and unadapted ACB strains was also shown. The 65.0 and 78.0 percent decline in the concentration of rare metals (gallium and germanium) respectively, have been registered. The recovery rates for other metals are slightly lower, but they are also sufficient to reduce the concentration of copper, lead, cadmium, zinc, nickel and aluminum in the waste dumps of fuel-energy complex. Principal possibility and prospects of using isolated strains and associations for processing complex technogenic raw materials, both to reduce its toxicity by leaching heavy metals, and isolate concomitant valuable rare metals - gallium and germanium were demonstrated in the study.

1. Baker B.J., Banfield J.F. Microbial communities in acid mine drainage. FEMS Microbiol. Ecol, 2003; 44:139-152.

[DOI:10.1016/S0168-6496(03)00028-X; Google Scholar] 
2. Bergey's Manual of Systematic Bacteriology. Vol. 2: The Proteobacteria, Part B: The Gammaproteobacteria. East Lansing, MI: Springer US, 2005. 1203 p. [DOI: https://doi.org/10.1007/0-387-28022-7; Google Scholar]

3. Blayda I.A., Vasyleva T.V., Baranov V.I., Semenov K.I., Slysarenko L.I., Barba I.M. Properties of chemolithotrophic bacteria new strains isolated from industrial substrates. Biotechnologia Acta, 2015; 8(6): 56-62.

[DOI: https://doi.org/10.15407/biotech8.06.056; Google Scholar]

4. Blayda I., Vasyleva T., Baranov V., Slysarenko L., Shulyakova S., Brodiazhenko T. Composition of aboriginal consortium of microorganisms from coal mines dumps. Studia Biologica, 2017; 11(2): 67-78.

[DOI: https://doi.org/10.30970/sbi.1102.528; Google Scholar]

5. Kanaeva Z.K., Bulaev A.G., Kanaev A.T., Kondrat'eva T.F. Physiological properties of Acidithiobacillus ferrooxidans strains isolated from sulfide ore deposits in Kazakhstan. Microbiology, 2015; 84(3): 370-376.

[DOI: https://doi.org/10.7868/S002636561503009X; Google Scholar]

6. Karavaiko G.I., Dubinina G.A., Kondrat'eva T.F. Lithotrophic microorganisms of the oxidative cycles of sulfur and iron. Microbiology, 2006; 75(5): 512-545.

[Google Scholar]

7. Karavaiko G.I., Kuznetsov S.I., Golomzik A.I. The role of microorganisms in the leaching of metals from ores. Moscow: Nauka, 1972. 248 p. (In Russian).

[Google Scholar]

8. Kelly D.P., Wood A.P. Reclassification of some species of Thiobacillus to the newly designated genera Acidithiobacillus gen. nov., Hallothiobacillus gen. nov. and Thermithiobacillus gen. nov. International Journal of Systematic and Evolutionary Microbiology. 2000; 50: 512-516.

[DOI: https://doi.org/10.1099/00207713-50-2-511; Google Scholar]

9. Kuzyakina T.I., Khainasova T.S., Levenets O.O. Biotechnology of extraction of metals from sulfidic ores. Bulletin of Kamchatka regional association "Educational-Scientific Center". Earth Sciences. 2008; 2(12): 76-86. (In Russian).

[Google Scholar]

10. Torma A.E. The role of Thiobacillus ferrooxidans in hydrometallurgical processes. Advances in Biochemical Engineering, 1977; 6: 1-37.

[DOI: https://doi.org/10.1007/3-540-08363-4_1; Google Scholar]

11. Trukhin Yu.P., Khainasova T.S., Rogatykh S. V. Isolation of chemolithotrophic microorganisms from Shanuch (Kamchatka) oxidized copper-nickel ore for bioleaching of sulphide ores. Proceedings of Universities. Applied Chemistry and Biotechnology, 2012; 1(2): 83-92. (In Russian).

[Google Scholar]

12. Tupikina O.V., Samorukova V.D., Kondrat'eva T.F. Patterns of growth and oxidation of natural pyrites by the representatives of acidophilic chemolithotrophic microorganisms. Microbiology, 2009; 78 (2): 170-179.

[Google Scholar]

\title{
ВИДІЛЕННЯ І ВИВЧЕННЯ ОСНОВНИХ ВЛАСТИВОСТЕЙ АЦИДОФІЛЬНИХ ХЕМОЛІТОТРОФНИХ БАКТЕРІЙ, ІЗОЛЬОВАНИХ ІЗ ВІДВАЛЬНИХ ПРОДУКТІВ ПАЛИВНО-ЕНЕРГЕТИЧНОГО КОМПЛЕКСУ УКРАЇНИ
}

\author{
I. Блайда*1, Т. Васильєва', Л. Слюсаренко1, \\ Н. Васильєва', В. Баранов², С. Шулякова \\ ${ }^{1}$ Одеський національний університет імені І. І. Мечникова \\ вул. Дворянська, 2, Одеса 65082, Україна
}

ISSN 1996-4536 (print) • ISSN 2311-0783 (on-line) • Біологічні Студії / Studia Biologica • 2018 • Том 12/№3-4 • C. 3-16 
2 Львівський національний університет імені Івана Франка вул. Грушевського, 4, Львів 79005, Україна

*e-mail: iblayda@ukr.net

Виділено чисті культури ацидофільних хемолітотрофних бактерій, мезофрільних і помірно термофільних, з ацидофільних аборигенних мікробних спільнот відвальних продуктів паливно-енергетичного комплексу України. Вивчено їхні основні біологічні та практично корисні властивості. Основні відмінності вивчених штамів спостерігали щодо енергетичних субстратів. Одну групу бактерій за здатністю окиснювати широкий спектр джерел енергії, зокрема, ферум (II), залучено до Acidithiobacillus ferrooxidans, іншу, що окиснює тільки сірку таїї відновлені сполуки, - до Acidithiobacillus thiooxidans. Усі мезофільні штами, незалежно від джерела виділення, незначно відрізнялися за здатністю до зростання і за накопиченням біомаси, проте інтенсивність окиснення двовалентного феруму була різною і не залежала від кількості біомаси. Порівняльний аналіз отриманих результатів дав змогу вважати $A$. ferrooxidans Lv red 9 і A. ferrooxidans Lv black 37 штамами, що мають максимальну окиснювальну активність. На їхньому прикладі показана здатність адаптуватися до нових субстратів, використовуючи їх як додаткове джерело мікроелементів і енергії. Встановлено високий рівень вилуговувальної активності виділених штамів. Як адаптовані, так і неадаптовані штами були здатні вилуговувати рідкісні метали - галій і германій - із відвальних продуктів на 65,0 і 78,0\% відповідно. Ефективність вилучення інших металів - купруму, плюмбуму, цинку, нікелю й алюмінію - була трохи нижчою, вона залежала від техногенного субстрату і штаму. Але цього було достатньо для зниження токсичності породних відвалів. Отримані результати дають підстави зробити висновок про значне поширення представників роду Acidithiobacillus у відвальних продуктах паливно-енергетичного комплексу, їхнє біологічне різноманіття і можливе застосування в біотехнологіях вилуговування металів.

Ключові слова: ацидофільні хемолітотрофні бактерії, відвальні продукти паливно-енергетичного комплексу, адаптація, вилуговувальна активність, германій, галій

Одержано: 25.09.2018

ISSN 1996-4536 (print) • ISSN 2311-0783 (on-line) • Біологічні Студії / Studia Biologica • 2018 • Том 12/№3-4 • C. 3-16 